\title{
Sistem Pendukung Keputusan Penerimaan Beasiswa Menggunakan Metode Weighted Product
}

\author{
Desfa Anisa ${ }^{1, *}$, Widya Septya Ningrum ${ }^{2}$, Retno Kusumo ${ }^{1}$, Widya Putri ${ }^{1}$ \\ ${ }^{1}$ Program Studi D-III RMIK, STIKes Awal Bros \\ Jalan Abulyatama Kelurahan Belian Kecamatan Batam Kota, Batam, Indonesia \\ ${ }^{2}$ Program Studi Sistem Informasi, Universitas Dinamika Bangsa \\ Jalan Jend. Sudirman, The Hok, Kec. Jambi Sel., Kota Jambi, Indonesia \\ Email: 1," desfaanisa24@gmail.com, ${ }^{2}$ widhyaseptyaningrum@gmail.com, ${ }^{3}$ retnokusumo76@ gmail.com, \\ ${ }^{4}$ widya.putri@awalbros.com \\ Email Penulis Korespondensi: desfaanisa24@gmail.com,
}

\begin{abstract}
Abstrak-Sistem pendukung keputusan ini dibuat untuk membantu pihak sekolah dalam pengambilan keputusan terkait dengan masalah penyeleksiaan beasiswa kepada siswa yang benar-benar layak untuk mendapatkan beasiswa, dimana proses penyeleksian beasiswa untuk siswa yang kurang mampu masih dilakukan secara manual. Dari setiap calon penerima beasiswa akan diseleksi berdasarkan kriteria, kriteria-kriteria tersebut terdiri dari pekerjaan orangtua, penghasilan orangtua, jumlah tanggungan orangtua dan nilai rata-rata raport. Metode yang digunakan dalam proses penyeleksiaan beasiswa adalah metode WP. Metode WP atau metode Weighted Product adalah salah satu metode yang digunakan dalam membantu proses pengambilan suatu keputusan dengan cara melakukan perkalian, dimana setiap rating atribut akan dipangkatkan dengan masing-masing bobot. Setelah itu hasil akhir dari perhitungan metode Weighted Product akan dilakukan proses perangkingan yang akan menentukan alternatif terpilih dalam proses penentuan penerimaan beasiswa. Tujuan dari penelitian ini adalah untuk membantu pihak sekolah dalam proses penyeleksian beasiswa untuk siswa yang kurang mampu. Perancangan dari sistem pendukung keputusan ini menggunakan diagram Unified Modelling Language dan dibangun dengan menggunakan bahasa pemograman PHP dan database MySQL. Hasil dari perhitungan yang telah dilakukan menggunakan metode Weighted Product didapatkan hasil dengan nilai tertinggi terdapat pada alternatif A8 dengan hasil nilai 0.2012 sehingga alternatif A8 merupakan alternatif terbaik dan bisa dijadikan sebagai rekomendasi calon penerima beasiswa.
\end{abstract}

Kata Kunci: Sistem Pendukung Keputusan; Beasiswa; Siswa; Metode; Weighted Product

Abstract-This decision support system was created to assist the school in making decisions related to the problem of selecting scholarships for students who really deserve to get scholarships, where the process of selecting scholarships for underprivileged students is still done manually. From each prospective scholarship recipient will be selected based on criteria, these criteria consist of parents' occupations, parents' income, number of dependents of parents and the average value of report cards. The method used in the scholarship selection process is the WP method. The WP method or the Weighted Product method is one of the methods used in helping the decision-making process by multiplying, where each attribute rating will be raised to the power of each weight. After that, the final result of the calculation of the Weighted Product method will be a ranking process that will determine the chosen alternative in the process of determining scholarship acceptance. The purpose of this research is to assist the school in the process of selecting scholarships for underprivileged students. The design of this decision support system uses Unified Modeling Language diagrams and is built using the PHP programming language and MySQL database. The results of the calculations that have been carried out using the Weighted Product method, the results with the highest value are found in alternative A8 with a value of 0.2012 so that alternative A8 is the best alternative and can be used as a recommendation for prospective scholarship recipients.

Keywords: Decision Support System; Scholarships; Students; Methods; Weighted Product

\section{PENDAHULUAN}

Perkembangan teknologi saat ini mengalami kemajuan yang sangat pesat, salah satunya adalah komputer. Teknologi komputer bukan menjadi hal yang asing bagi kalangan masyarakat, terlebih bagi yang memang terlibat langsung dalam dunia komputer. Salah satu bidang yang menggunakan komputer adalah bidang pendidikan. Pendidikan ini sangatlah penting bagi masyarakat, dimana pemerintah sangat mendukung setiap masyarakat untuk meraih pendidikan setinggitingginya. Saat ini sudah banyak yang memberikan beasiswa baik dari pemerintah maupun lembaga pendidikan untuk membantu siswa atau mahasiswa selama menempuh studinya sesuai dengan kriteria yang ditentukan. Beasiswa bisa dikatakan sebagai bantuan berupa biaya keuangan yang diberikan kepada seseorang untuk meningkatkan SDM atau sumber daya manusia melalui pendidikan [1]. Bantuan program beasiswa ini memiliki kriteria tersendiri untuk mendapatkannya bagi seseorang yang layak menerima beasiswa tersebut [2].

Dukungan komputerisasi sangat dibutuhkan dalam kehidupan sehari-hari dan sudah merambah ke segala bidang termasuk dalam proses pengambilan suatu keputusan. Sistem pendukung keputusan yang dirancang dengan menggunakan teknologi komputer dirasa sangat efektif. Sehingga dalam proses seleksi penerimaan beasiswa yang melibatkan beberapa kriteria diperlukan sebuah sistem pendukung keputusan yang berbasis komputerisasi yang dapat membantu dalam menentukan alternatif pemilihan penerima beasiswa. Pengambilan keputusan dapat diartikan sebagai kegiatan memilih alternative terbaik dari beberapa alternative yang ada [3]. Sistem pendukung keputusan atau bisa juga disebut sebagai Decision Support System (DSS) adalah sebuah sistem berbasis komputer yang dibuat untuk dapat membantu manajer dalam proses pengambilan keputusan dan menyelesaikan suatu masalah [4]. Sistem pendukung keputusan memiliki tujuan dalam memberikan informasi kepada para pengambil keputusan sehingga pengambil keputusan dapat memberikan keputusan yang lebih efektif dan tepat sasaran [5]. 
Program penerimaan beasiswa di SMK Pelita Raya Kota Jambi dilakukan setiap tahunnya yang diberikan kepada siswa yang kurang mampu, dimana proses penyeleksian beasiswa untuk siswa yang kurang mampu masih dilakukan secara manual. Untuk mendapatkan beasiswa harus sesuai dengan kriteria yang ditetapkan. Sehingga, tidak semua siswa mendapatkan beasiswa tersebut, hanya siswa yang memenuhi kriteria saja yang akan memperoleh beasiswa. Kriteria yang digunakan terdiri dari pekerjaan orangtua, penghasilan orangtua, jumlah tanggungan orangtua dan nilai rata-rata raport. Agar penyeleksian efektif dan dapat menghasilkan informasi yang cepat dan akurat maka diperlukan sebuah sistem pendukung keputusan yang dapat membantu pihak sekolah dalam menyeleksi siswa yang berhak dalam menerima beasiswa. Bedasarkan uraian pembahasan yang telah dipaparkan, maka penulis merancang sebuah sistem dengan judul "Perancangan Sistem Pendukung Keputusan Penerimaan Beasiswa Menggunakan Metode Weighted Product."

Ada beberapa penelitian yang sudah pernah dilakukan oleh peneliti sebelumnya yang berhubungan dengan sistem pendukung keputusan penerimaan beasiswa yaitu penelitian yang dilakukan oleh Liesnaningsih dkk dengan judul Sistem Pendukung Keputusan Penerima Beasiswa Berbasis WEB Menggunakan Metode Simple Additive Weighting pada Pondok Pesantren Daarul Ahsan. Pada penelitian tersebut calon penerima beasiswa dalam memperoleh beasiswa harus memenuhi syarat yang telah ditentukan seperti nilai rata-rata raport, penghasilan orang tua, jumlah tanggungan orang tua, kedisiplinan dan organisasi. Metode yang digunakan yaitu metode Simple Additive Weighting (SAW) [6].

Pada penelitian yang telah dilakukan oleh Andani dengan judul Penerapan Metode SMART Dalam Pengambilan Keputusan Penerimaan Beasiswa Yayasan AMIK Tunas Bangsa. Kriteria yang digunakan untuk sistem pendukung keputusan penerimaan beasiswa dalam penelitian ini yaitu IPK, pendapatan orang tua dan jumlah tanggungan orang tua. Metode yang digunakan yaitu metode Simple Multi Attribute Rating Technique. Hasil dari penelitian ini berupa perangkingan yang akan dibuat rekomendasi untuk calon penerima beasiswa yang diberikan untuk mahasiswa berprestasi dan mahasiswa kurang mampu [7].

Pada penelitian yang telah dilakukan oleh Satria dkk dengan judul Penerapan Metode Electre Sebagai Sistem Pendukung Keputusan Dalam Penerimaan Beasiswa. Kriteria yang digunakan untuk sistem pendukung keputusan penerimaan beasiswa dalam penelitian ini terdiri dari IPK, penghasilan pertahun, jumlah tanggungan dan pekerjan orangtua. Metode yang digunakan yaitu metode Elimination Et Choix Traduisant La Realite. Sistem pendukung keputusan dirancang dengan bahasa pemrograman Visual Basic Net 2010 [8].

Pada penelitian yang telah dilakukan oleh Sibyan dengan judul Implementasi Metode SMART Pada Sistem Pendukung Keputusan Penerima Beasiswa Sekolah. Kriteria yang digunakan untuk sistem pendukung keputusan penerimaan beasiswa dalam penelitian ini terdiri dari rangking paralel, prestasi, kondisi ekonomi dan hafalan Al-Qur'an. Metode yang digunakan yaitu metode Simple Multi Attribute Rating Technique [9].

Pada penelitian yang telah dilakukan oleh Muqorobbin dengan judul Sistem Pendukung Keputusan Seleksi Penerimaan Beasiswa Dengan Metode SAW. Tujuan dari penelitian ini adalah membangun sebuah sistem pendukung keputusan untuk menentukan calon penerima beasiswa bagi siswa berprestasi dan kurang mampu menggunakan satu metode yaitu metode Simple Additive Weighting. Kriteria yang digunakan untuk sistem pendukung keputusan penerimaan beasiswa dalam penelitian ini terdiri dari Nilai raport, penghasilan dan tanggungan anak [10].

Berdasarkan paparan yang telah diuraikan pada penelitian sebelumnya maka yang dilakukan pada penelitian ini adalah merancang sebuah sitem pendukung keputusan penerimaan beasiswa dengan menggunakan metode Weighted Product. Kriteria yang digunakan untuk sistem pendukung keputusan penerimaan beasiswa dalam penelitian ini terdiri dari pekerjaan orangtua, penghasilan orangtua, jumlah tanggungan orangtua dan nilai rata-rata raport. Sitem pendukung keputusan ini dirancang menggunakan diagram Unified Modelling Language dan dibangun menggunakan bahasa pemrograman PHP dan database MySQL.

\section{METODOLOGI PENELITIAN}

\subsection{Metode Weighted Product}

Metode Weighted Product (WP) merupakam metode yang menggunakan perkalian untuk menghubungkan rating atribut, dimana setiap rating atribut akan dipangkatkan dulu dengan masing-masing bobot atribut yang bersangkutan. Proses ini juga sama dengan proses normalisasi. Metode Weighted Product mirip dengan metode Weighted Sum (WS), hanya saja pada metode Weighted Product terdapat perkalian dalam perhitungannya. Metode Weighted Product juga disebut sebagai analisis berdimensi karena struktur perhitungannya menghilangkan satuan ukuran [4]. Langkah-langkah yang dilakukan dalam perhitungan metode Weighted Product adalah sebagai berikut :

a. Menentukan kriteria yang akan menjadi acuan dalam proses pengambilan keputusan.

b. Menentukan bobot disetiap kriteria.

c. Menghitung perbaikan nilai bobot.

d. Menentukan rating kecocokan alternatif pada setiap kriteria.

e. Menghitung nilai Vektor S

Perhitungan ini dilakukan dengan mengalikan seluruh alternatif pada setiap kriteria tetapi sebelumnya dilakukan pemangkatan dulu dengan bobot dari masing-masing kriteria. Untuk atribut benefit berpangkat positif dan atribut Cost berpangkat negatif. Perhitungan nilai Vektor S dapat dilakukan dengan rumus sebagai berikut ini : 


\section{TIN: Terapan Informatika Nusantara}

Vol 2, No 8, Januari 2022, Hal 483-491

ISSN 2722-7987 (Media Online)

Website https://ejurnal.seminar-id.com/index.php/tin

DOI 10.47065/tin.v2i8.1064

$$
S_{i}=\prod_{j=1}^{n} x_{i j} w_{j}
$$

Keterangan :
$\mathrm{S} \quad$ : Preferensi alternatif yang dianalogikan sebagai vektor S
$\mathrm{X}$ : Nilai kriteria
W : Bobot kriteria
i : Alternatif
j : Kriteria
n : Banyaknya kriteria

f. Menghitung nilai Vektor V

Perhitungan Vektor V dilakukan dengan cara membagi nilai masing-masing Vektor S dengan jumlah dari seluruh nilai S. Perhitungan nilai Vektor V dapat dilakukan dengan rumus sebagai berikut ini :

$$
V_{i}=\frac{\prod_{\mathrm{J}=1}^{\mathrm{n}} \mathrm{x}_{\mathrm{ij}} \mathrm{w}_{\mathrm{j}}}{\prod_{\mathrm{J}=1}^{\mathrm{n}}\left(\mathrm{x}_{\mathrm{j} *}\right) \mathrm{w}_{\mathrm{j}}}
$$

Keterangan :
$\mathrm{V}$ : Preferensi alternatif yang dianalogikan sebagai vektor $\mathrm{V}$
$\mathrm{X}$ : Nilai kriteria
W : Bobot kriteria
i : Alternatif
j : Kriteria
n : Banyaknya kriteria
g. Melakukan perangkingan pada hasil Vektor V

\subsection{Tahapan Penelitian}

Alur atau tahapan dari penelitian ini dapat dilihat pada gambar 1.

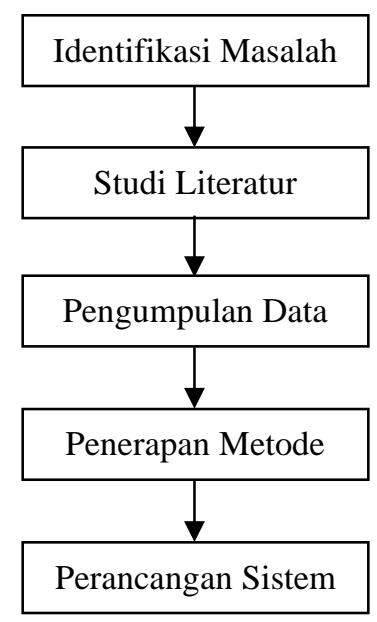

Gambar 1. Alur Penelitian

Penjelasan dari masing-masing alur penelitian pada gambar 1 adalah sebagai berikut :

a. Identifikasi Masalah

Pada tahap identifikasi masalah dilakukan dengan menganalisa masalah yang akan diteliti dan menentukan metode apa yang akan digunakan pada penelitian ini.

b. Studi Literatur

Pada tahap studi literatur, penulis mencari beberapa referensi yang mendukung dari berbagai jurnal ilmiah dan bukubuku yang relevan dengan penelitian yang dilakukan.

c. Pengumpulan Data

Pada tahap ini, untuk mendapatkan data dan informasi yang diperlukan maka pengumpulan data dilakukan dengan observasi dan wawancara pada lokasi penelitian.

d. Penerapan Metode

Pada tahap ini metode yang digunakan dalam sistem pendukung keputusan penerimaan beasiswa yaitu menggunakan metode Weighted Product. 


\section{TIN: Terapan Informatika Nusantara}

Vol 2, No 8, Januari 2022, Hal 483-491

ISSN 2722-7987 (Media Online)

Website https://ejurnal.seminar-id.com/index.php/tin

DOI 10.47065/tin.v2i8.1064

e. Perancangan Sistem

Pada tahap ini sistem pendukung keputusan dibangun dengan menggunakan bahasa pemograman PHP, database

MySQL dan dirancang dengan menggunakan diagram Unified Modelling Language.

\section{HASIL DAN PEMBAHASAN}

\subsection{Perhitungan Metode Weighted Product}

Dalam penelitian ini terdapat bobot dan kriteria yang akan digunakan untuk menyeleksi calon penerima beasiswa.

Tabel 2. Kriteria dan Bobot

\begin{tabular}{clcc}
\hline Kode & \multicolumn{1}{c}{ Kriteria } & Bobot & Atribut \\
\hline C1 & Pekerjaan orang tua & 1 & Benefit \\
C2 & Penghasilan orang tua & 1 & Cost \\
C3 & Jumlah tanggungan orang tua & 0.75 & Benefit \\
C4 & Nilai rata-rata raport & 0.5 & Benefit \\
\hline
\end{tabular}

Tabel 3. Keterangan Pembobotan Masing-Masing Kriteria

\begin{tabular}{|c|c|c|c|c|}
\hline No & Kode & Kriteria & Keterangan & Bobot \\
\hline 1 & $\mathrm{C} 1$ & Pekerjaan orang tua & $\begin{array}{l}\text { PNS } \\
\text { Karyawan Swasta } \\
\text { Wiraswasta } \\
\text { Buruh } \\
\text { Petani }\end{array}$ & $\begin{array}{c}0 \\
0.25 \\
0.5 \\
0.75 \\
1\end{array}$ \\
\hline 2 & $\mathrm{C} 2$ & Penghasilan orang tua & $\begin{array}{l}<=\text { Rp. } 500.0000 \\
>\text { Rp. } 500.0000 \mathrm{~s} / \mathrm{d}<\text { Rp. } 1.000 .000 \\
>\text { Rp. } 1.000 .000 \mathrm{~s} / \mathrm{d}<\text { Rp. } 1.500 .000 \\
>\text { Rp. } 1.500 .000 \mathrm{~s} / \mathrm{d}<\text { Rp. } 2.000 .000 \\
>=\text { Rp. } 2.000 .000\end{array}$ & $\begin{array}{c}1 \\
0.75 \\
0.5 \\
0.25 \\
0\end{array}$ \\
\hline 3 & $\mathrm{C} 3$ & Jumlah tanggungan orang tua & $\begin{array}{l}1 \text { orang anak } \\
2 \text { orang anak } \\
3 \text { orang anak } \\
4 \text { orang anak } \\
\text { lebih dari } 4 \text { orang anak }\end{array}$ & $\begin{array}{c}0 \\
0.25 \\
0.5 \\
0.75 \\
1\end{array}$ \\
\hline 4 & $\mathrm{C} 4$ & Nilai rata-rata raport & $\begin{array}{l}<7.0 \\
>=7.0 \mathrm{~s} / \mathrm{d}<=7.5 \\
>7.5 \mathrm{~s} / \mathrm{d}<=8.0 \\
>8.0\end{array}$ & $\begin{array}{c}0.25 \\
0.5 \\
0.75 \\
1\end{array}$ \\
\hline
\end{tabular}

Perbaikan nilai bobot $(\mathrm{Wj})$ dihitung berdasarkan bobot dari setiap kriteria yang sudah ditentukan dengan membagi bobot dengan jumlah dari masing-masing bobot.

$$
\begin{aligned}
& \mathrm{W}_{1}=\frac{1}{1+1+0,75+0,5}=0,3077 \\
& \mathrm{~W}_{2}=\frac{1}{1+1+0,75+0,5}=0,3077 \\
& \mathrm{~W}_{3}=\frac{0,75}{1+1+0,75+0,5}=0,2308 \\
& \mathrm{~W}_{4}=\frac{0,5}{1+1+0,75+0,5}=0,1538
\end{aligned}
$$

Tabel 4. Rating Kecocokan Alternatif Pada Setiap Kriteria

\begin{tabular}{ccccc}
\hline \multirow{2}{*}{ Alternatif } & \multicolumn{5}{c}{ Kriteria } \\
\cline { 2 - 5 } & $\mathrm{C} 1$ & $\mathrm{C} 2$ & $\mathrm{C} 3$ & $\mathrm{C} 4$ \\
\hline A1 & 1 & 0,5 & 0,25 & 0,5 \\
A2 & 0,5 & 0,5 & 0,25 & 0,5 \\
A3 & 1 & 0,5 & 0 & 0,5 \\
A4 & 0,5 & 0,5 & 0,5 & 0,5 \\
A5 & 0,5 & 0,25 & 0 & 0,5 \\
\hline
\end{tabular}




\section{TIN: Terapan Informatika Nusantara}

Vol 2, No 8, Januari 2022, Hal 483-491

ISSN 2722-7987 (Media Online)

Website https://ejurnal.seminar-id.com/index.php/tin

DOI 10.47065/tin.v2i8.1064

\begin{tabular}{ccccc}
\hline \multirow{2}{*}{ Alternatif } & \multicolumn{5}{c}{ Kriteria } \\
\cline { 2 - 5 } & $\mathrm{C} 1$ & $\mathrm{C} 2$ & $\mathrm{C} 3$ & $\mathrm{C} 4$ \\
\hline A6 & 0,75 & 0,75 & 0,5 & 0,75 \\
A7 & 0,25 & 0 & 0,25 & 0,5 \\
A8 & 0,75 & 0,75 & 1 & 0,75 \\
A9 & 0,25 & 0 & 0,75 & 0,75 \\
A10 & 0,25 & 0,5 & 0,75 & 1 \\
\hline
\end{tabular}

Perhitungan nilai Vektor $S_{i}$ dilakukan dengan cara mengalikan seluruh alternatif pada setiap kriteria tetapi sebelumnya dilakukan pemangkatan dulu dengan bobot dari masing-masing kriteria. Untuk atribut benefit berpangkat positif dan atribut cost berpangkat negatif.

$$
\begin{array}{lll}
S_{1}=\left(1^{0,3077}\right) \times\left(0,5^{-0,3077}\right) \times\left(0,25^{0,2308}\right) \times\left(0,5^{0,1538}\right) & =0,8079 \\
S_{2}=\left(0,5^{0,3077}\right) \times\left(0,5^{-0,3077}\right) \times\left(0,25^{0,2308}\right) \times\left(0,5^{0,1538}\right) & =0,6528 \\
S_{3}=\left(1^{0,3077}\right) \times\left(0,5^{-0,3077}\right) \times\left(0^{0,2308}\right) \times\left(0,5^{0,1538}\right) & =0 \\
S_{4}=\left(0,5^{0,3077}\right) \times\left(0,5^{-0,3077}\right) \times\left(0,5^{0,2308}\right) \times\left(0,5^{0,1538}\right) & =0,7660 \\
S_{5}=\left(0,5^{0,3077}\right) \times\left(0,25^{-0,3077}\right) \times\left(0^{0,2308}\right) \times\left(0,5^{0,1538}\right) & =0 \\
S_{6}=\left(0,75^{0,3077}\right) \times\left(0,75^{-0,3077}\right) \times\left(0,5^{0,2308}\right) \times\left(0,75^{0,1538}\right) & =0,8153 \\
S_{7}=\left(0,25^{0,3077}\right) \times\left(0^{-0,3077}\right) \times\left(0,25^{0,2308}\right) \times\left(0,5^{0,1538}\right) & =0 \\
S_{8}=\left(0,75^{0,3077}\right) \times\left(0,75^{-0,3077}\right) \times\left(1^{0,2308}\right) \times\left(0,75^{0,1538}\right) & =0,9567 \\
S_{9}=\left(0,25^{0,3077}\right) \times\left(0^{-0,3077}\right) \times\left(0,75^{0,2308}\right) \times\left(0,75^{0,1538}\right) & =0 \\
S_{10}=\left(0,25^{0,3077}\right) \times\left(0,5^{-0,3077}\right) \times\left(0,75^{0,2308}\right) \times\left(1^{0,1538}\right) & =0,7560
\end{array}
$$

Perhitungan nilai Vektor V dilakukan dengan membagi hasil nilai Vektor S dengan jumlah dari seluruh nilai Vektor S.

$$
\begin{aligned}
& \mathrm{V}_{1}=\frac{0,8079}{0,8079+0,6528+0+0,7660+0+0,8153+0+0,9567+0+0,7560}=0,1699 \\
& \mathrm{~V}_{2}=\frac{0,6528}{0}=0,1373 \\
& \mathrm{~V}_{3}=\frac{0,8079+0,6528+0+0,7660+0+0,8153+0+0,9567+0+0,7560}{0,8079+0,6528+0+0,7660+0+0,8153+0+0,9567+0+0,7560}=0 \\
& \mathrm{~V}_{4}=\frac{0,7660}{0,8079+0,6528+0+0,7660+0+0,8153+0+0,9567+0+0,7560}=0,1611 \\
& \mathrm{~V}_{5}=\frac{0}{0,8079+0,6528+0+0,7660+0+0,8153+0+0,9567+0+0,7560}=0 \\
& \mathrm{~V}_{6}=\frac{0,8153}{0,8079+0,6528+0+0,7660+0+0,8153+0+0,9567+0+0,7560}=0,1715 \\
& \mathrm{~V}_{7}=\frac{0}{0,8079+0,6528+0+0,7660+0+0,8153+0+0,9567+0+0,7560}=0,2012 \\
& \mathrm{~V}_{8}=\frac{0,9567}{0,8079+0,6528+0+0,7660+0+0,8153+0+0,9567+0+0,7560}=0 \\
& \mathrm{~V}_{9}=\frac{0}{0,8079+0,6528+0+0,7660+0+0,8153+0+0,9567+0+0,7560} \\
& \mathrm{~V}_{10}=\frac{0,7560}{0,8079+0,6528+0+0,7660+0+0,8153+0+0,9567+0+0,7560}
\end{aligned}
$$

Dari hasil perhitungan Vektor V, maka langkah selanjutnya adalah melakukan perangkingan dari hasil perhitungan Vektor V. Hasil perangkingan dapat dilihat pada tabel 5.

Tabel 5. Hasil Perangkingan

\begin{tabular}{ccc}
\hline Alternatif & Nilai Preferensi & Peringkat \\
\hline A8 & 0,2012 & 1 \\
A6 & 0,1715 & 2 \\
A1 & 0,1699 & 3
\end{tabular}


TIN: Terapan Informatika Nusantara

Vol 2, No 8, Januari 2022, Hal 483-491

ISSN 2722-7987 (Media Online)

Website https://ejurnal.seminar-id.com/index.php/tin

DOI 10.47065/tin.v2i8.1064

\begin{tabular}{ccc}
\hline Alternatif & Nilai Preferensi & Peringkat \\
\hline A4 & 0,1611 & 4 \\
A10 & 0,1590 & 5 \\
A2 & 0,1373 & 6 \\
A3 & 0 & 7 \\
A5 & 0 & 8 \\
A7 & 0 & 9 \\
A9 & 0 & 10 \\
\hline
\end{tabular}

\subsection{Use Case Diagram}

Use case diagram adalah diagram yang menjelaskan tentang bagaimana cara kerja dari sistem yang akan dibangun dan menjelaskan kegiatan-kegiatan yang dilakukan oleh aktor sebagai penggunanya. Use case diagram perancangan sistem pendukung keputusan penerimaan beasiswa menggunakan metode WP dapat dilihat pada gambar 2 .

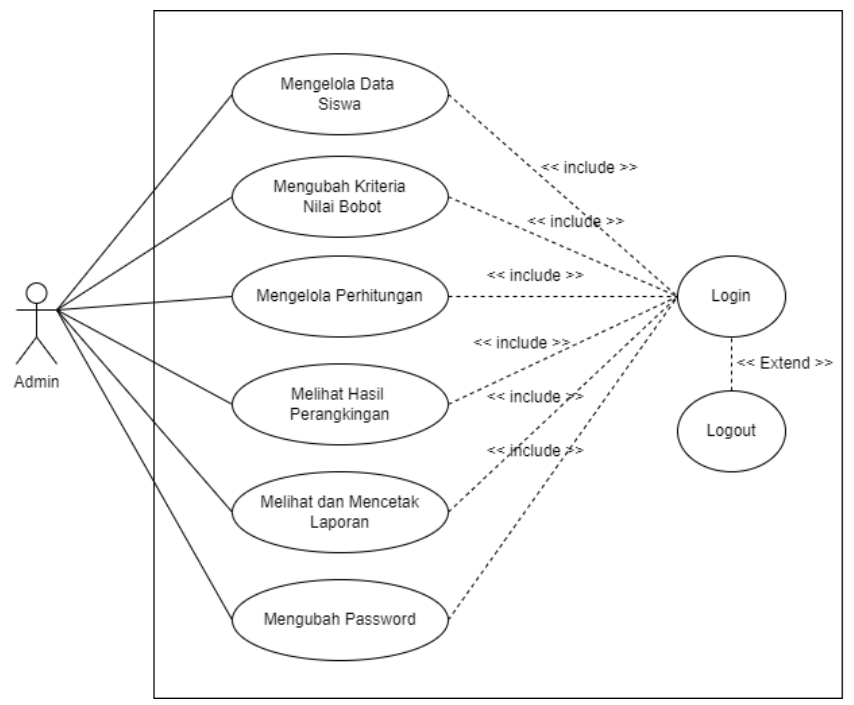

Gambar 2. Use Case Diagram

\subsection{Class Diagram}

Class Diagram adalah menggambarkan kelas berikut perilaku dan keadaan dengan menghubungkan antar kelas. Class Diagram dari perancangan sistem pendukung keputusan penerimaan beasiswa menggunakan metode Weighted Product dapat dilihat pada gambar 3 .

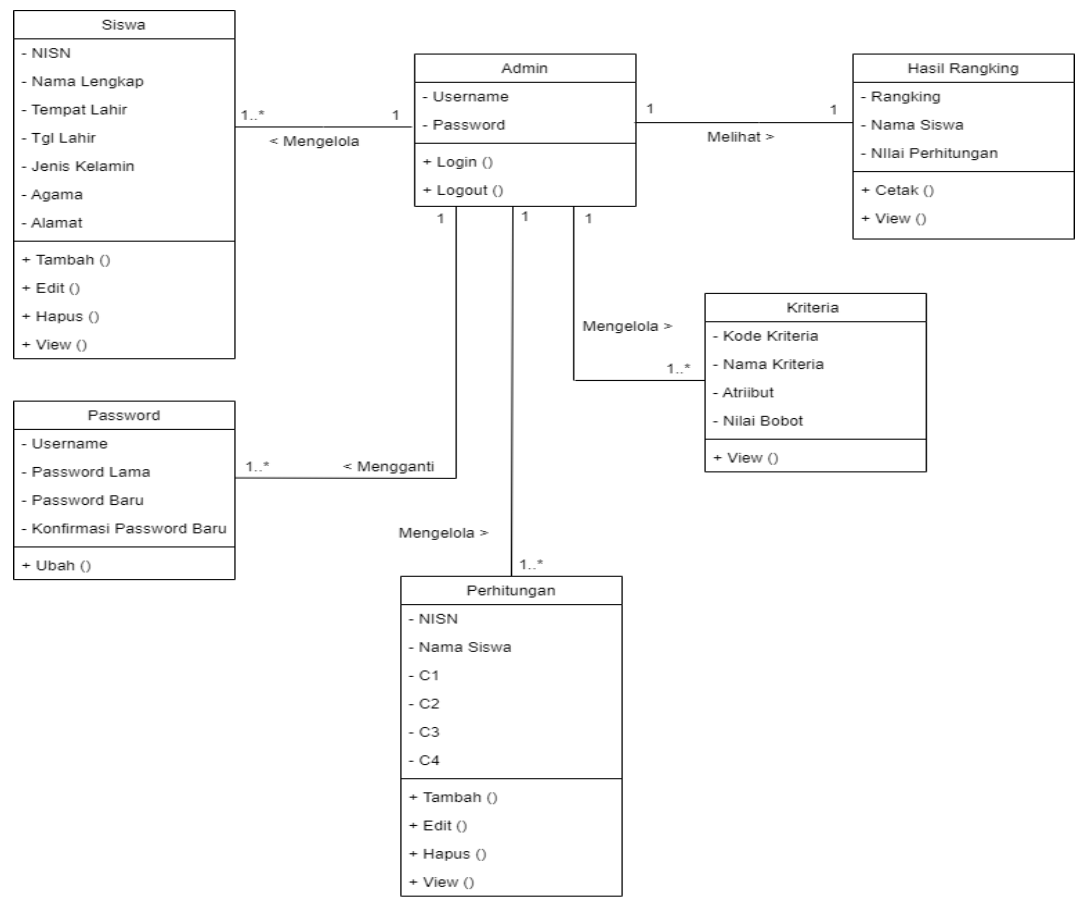

Gambar 3. Class Diagram 
TIN: Terapan Informatika Nusantara

Vol 2, No 8, Januari 2022, Hal 483-491

ISSN 2722-7987 (Media Online)

Website https://ejurnal.seminar-id.com/index.php/tin

DOI 10.47065/tin.v2i8.1064

\subsection{Implementasi Program}

\section{a. Halaman Login}

Halaman login ini dapat digunakan oleh user untuk masuk kedalam sistem. Pengguna yang akan mengakses sistem harus memasukan username dan password terlebih dahulu. Tampilan dari halaman login dapat dilihat pada gambar 4 .

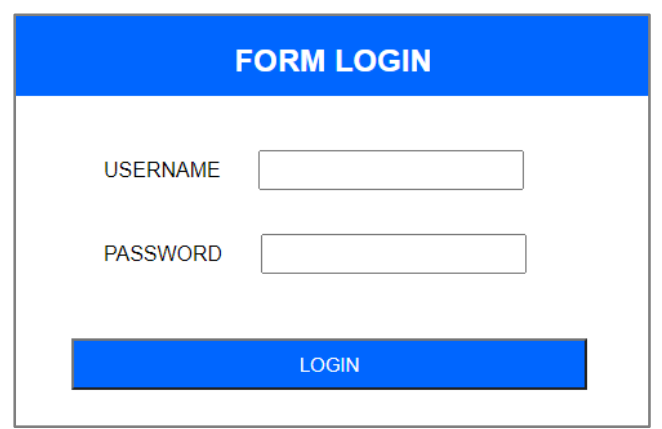

Gambar 4. Tampilan Halaman Login

\section{b. Halaman Data Siswa}

Halaman data siswa ini dapat digunakan oleh user untuk mengelola data-data siswa seperti menambah, mengubah dan menghapus data siswa. Tampilan dari halaman data siswa dapat dilihat pada gambar 5.

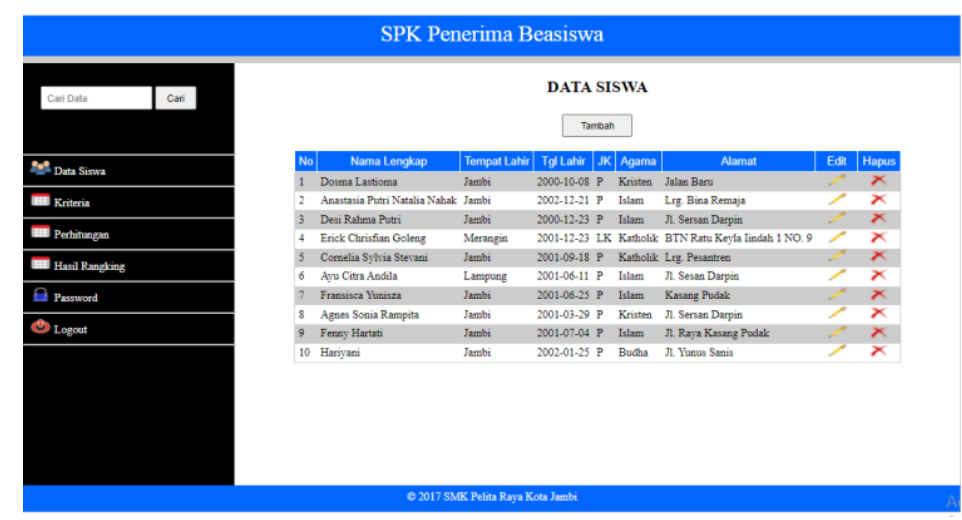

Gambar 5. Tampilan Halaman Data Siswa

\section{c. Halaman Kriteria}

Halaman data kriteria ini dapat digunakan oleh user untuk mengelola data-data kriteria seperti menambah, mengubah dan menghapus data kriteria. Tampilan dari halaman data kriteria dapat dilihat pada gambar 6.

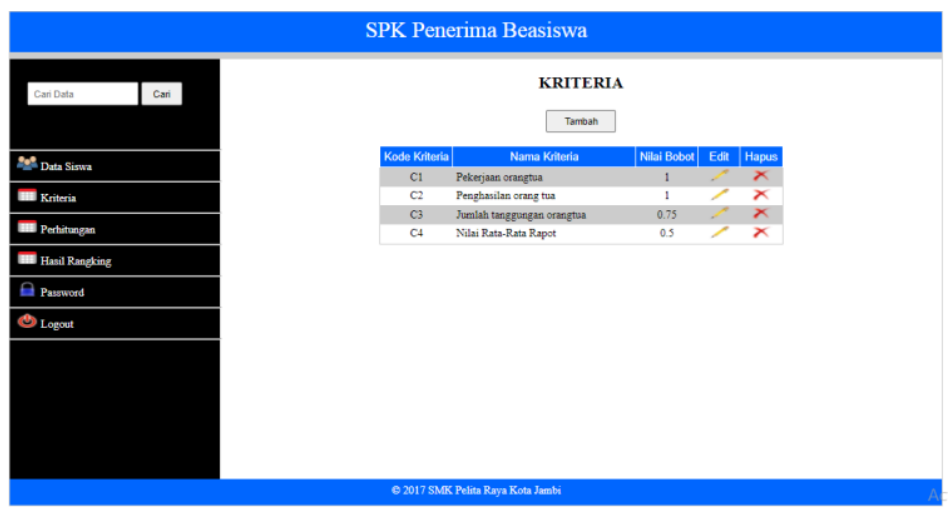

Gambar 6. Tampilan Halaman Kriteria

\section{d. Halaman Data Perhitungan}

Halaman data perhitungan ini dapat digunakan oleh user untuk mengelola data-data perhitungan seperti menambah, mengubah dan menghapus data perhitungan. Tampilan dari halaman data perhitungan dapat dilihat pada gambar 7 . 


\section{TIN: Terapan Informatika Nusantara}

Vol 2, No 8, Januari 2022, Hal 483-491

ISSN 2722-7987 (Media Online)

Website https://ejurnal.seminar-id.com/index.php/tin

DOI 10.47065/tin.v2i8.1064

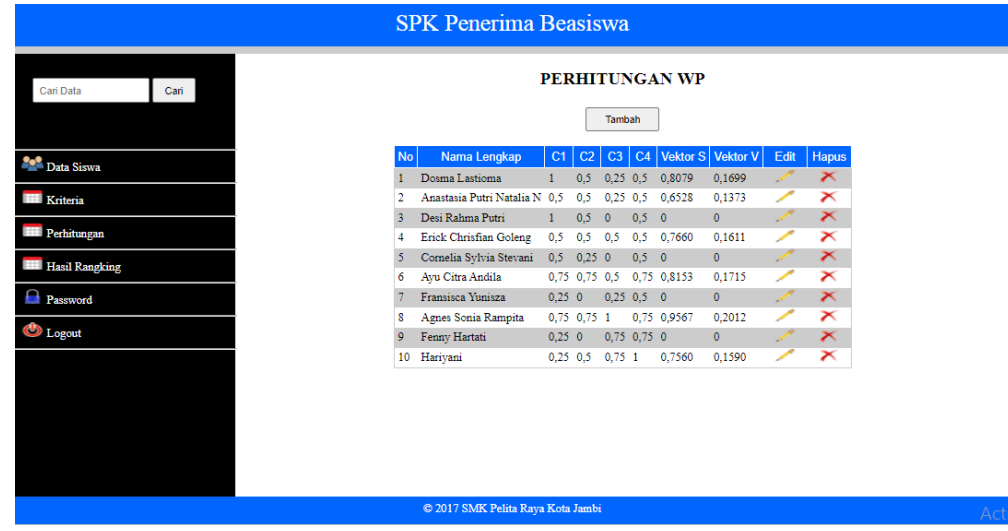

Gambar 7. Tampilan Halaman Data Perhitungan

\section{e. Halaman Hasil Perangkingan}

Halaman hasil perangkingan adalah halaman yang digunakan untuk siswa yang akan mendapatkan beasiswa berdasarkan nilai rangking dari perhitungan metode WP. Berikut adalah tampilan dari halaman hasil perangkingan :

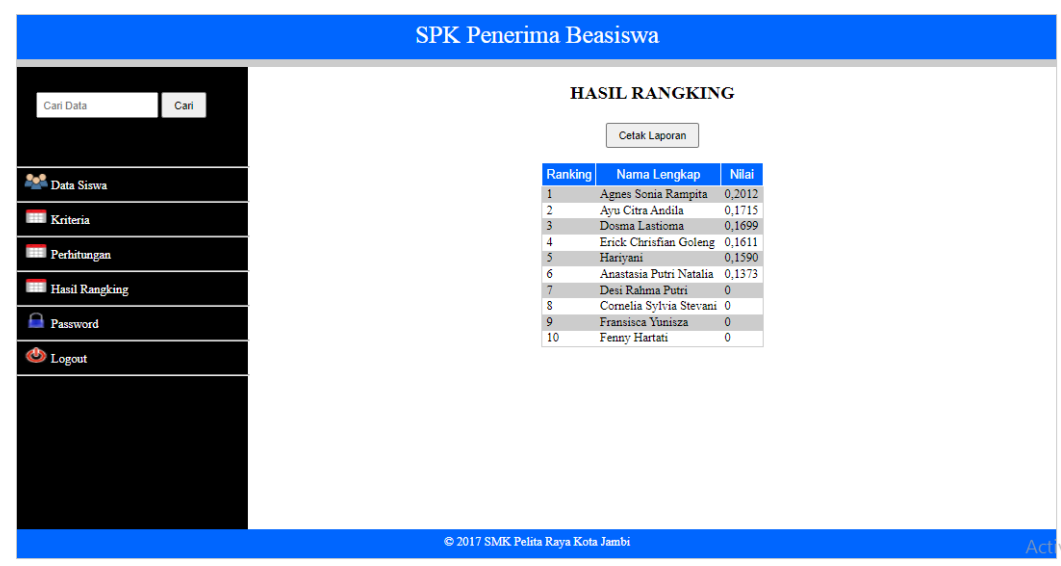

Gambar 8. Tampilan Halaman Hasil Perangkingan

\section{KESIMPULAN}

Berdasarkan dari pembahasan yang sudah dipaparkan, maka ada beberapa hal yang dapat disimpulkan dari penelitian ini yaitu perancangan sistem pendukung keputusan ini dibangun dengan bahasa pemograman PHP dan database MySQL untuk membantu pihak sekolah dalam menyeleksi calon penerima beasiswa agar dapat mempercepat dan memberikan rekomendasi calon penerima beasiswa. Dalam proses seleksi peneriman beasiswa tersebut menggunakan beberapa kriteria yaitu pekerjaan orangtua, penghasilan orangtua, jumlah tanggungan orangtua dan nilai rata-rata raport. Metode yang digunakan dalam proses penyeleksiaan beasiswa adalah metode WP. Dari perhitungan metode Weighted Product didapatkan hasil dengan nilai tertinggi yaitu terdapat pada alternatif A8 dengan nilai 0,2012, sehingga dari hasil perhitungan tersebut bisa dijadikan rekomendasi dalam proses penyeleksian calon penerima beasiswa.

\section{REFERENCES}

[1] R. D. Mainingsih and M. Hamka, "Sistem Pendukung Keputusan Untuk Menentukan Penerima Bantuan Beasiswa dengan Metode AHP dan TOPSIS," vol. 18, no. 1, pp. 65-74, 2021.

[2] B. Fajariyanto and R. T. Wahyuningrum, "Kajian Literatur Sistem Pendukung Keputusan Penerimaan Beasiswa," J. Simantec, vol. 9, no. 2, pp. 45-50, 2021.

[3] Diana, Metode dan Aplikasi Sistem Pendukung Keputusan. Yogyakarta : Deepublish, 2018.

[4] F. Sari, Metode Dalam Pengambilan Keputusan. Yogyakarta : Deepublish, 2018.

[5] Y. Amaliah, "Sistem Pendukung Keputusan Penerima Beasiswa Tidak Mampu Menggunakan Metode Moora," vol. 5, no. 1, pp. $12-18,2021$.

[6] L. Liesnaningsih, R. Taufiq, R. Destriana, and A. P. Suyitno, "Sistem Pendukung Keputusan Penerima Beasiswa Berbasis WEB Menggunakan Metode Simple Additive Weighting (SAW) pada Pondok Pesantren Daarul Ahsan,” J. Inform. Univ. Pamulang, vol. 5, no. 1, p. 54, 2020.

[7] S. R. Andani, "Penerapan Metode SMART dalam Pengambilan Keputusan Penerima Beasiswa Yayasan AMIK Tunas Bangsa," J. Sist. dan Teknol. Inf., vol. 7, no. 3, p. 166, 2019.

[8] B. Satria et al., "Penerapan Metode Electre Sebagai Sistem Pendukung Keputusan Dalam Penerimaan Beasiswa," Cetak) Bul. Utama Tek., vol. 14, no. 3, pp. 1410-4520, 2019. 


\section{TIN: Terapan Informatika Nusantara}

Vol 2, No 8, Januari 2022, Hal 483-491

ISSN 2722-7987 (Media Online)

I. Website https://ejurnal.seminar-id.com/index.php/tin DOI 10.47065/tin.v2i8.1064

[9] H. Sibyan, "Implementasi Metode SMART Pada Sistem Pendukung Keputusan Penerima Beasiswa Sekolah,” J. Penelit. dan Pengabdi. Kpd. Masy. UNSIQ, vol. 7, no. 1, pp. 78-83, 2020.

[10] Muqorobin, A. Apriliyani, and Kusrini, "Sistem Pendukung Keputusan Seleksi Penerimaan Beasiswa Dengan Metode SAW," J. Ilm. Teknol. Inf. Terap., vol. 14, no. 01, pp. 76-85, 2019. 